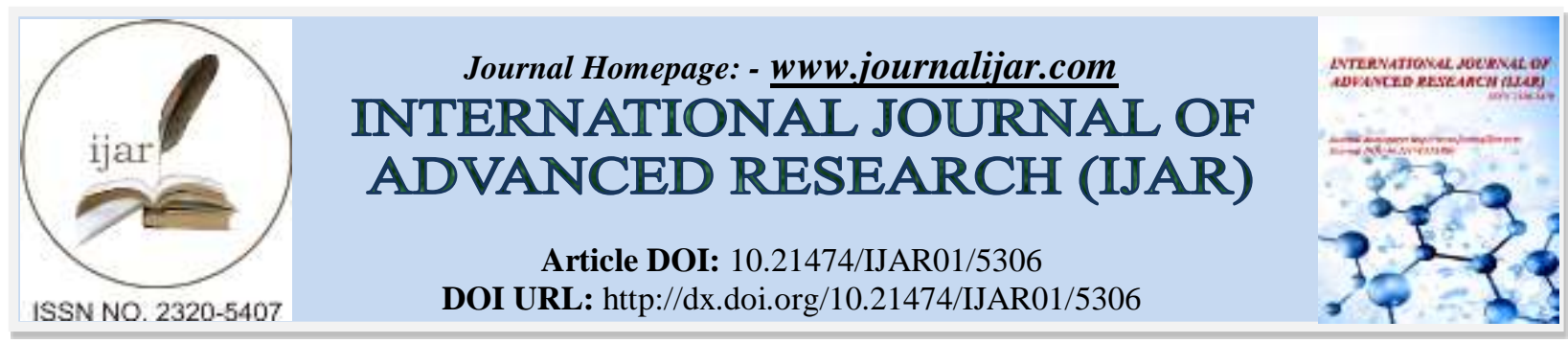

RESEARCH ARTICLE

\title{
EFFECT OF GROWTH REGULATORS ON YIELD AND QUALITY OF WINTER GUAVA CV. ALLAHABAD SAFEDA.
}

\section{Sandeep Kaur ${ }^{1}$ and Amarjeet Kaur ${ }^{2}$.}

1. MSc research student ${ }^{1}$ Department of Horticulture, Khalsa College, (GNDU)Amritsar-143001.

2. Assistant Professor ${ }^{2}$ Department of Horticulture, Khalsa College, (GNDU)Amritsar-143001.

\section{Manuscript Info}

Manuscript History

Received: 02 July 2017

Final Accepted: 04 August 2017

Published: September 2017

Key words:-

Guava, Allahabad Safeda, NAA, 2,4-D, yield, quality, TSS, Brix, Urea.

\begin{abstract}
An experiment was conducted at the department of Horticulture, Khalsa College, Amritsar(Punjab) during the year 2016-17 to study the role of foliar spray of NAA(50,75,100 ppm), 2,4-D (30,40,50ppm) and Urea $(1 \%, 1.5 \%$ and $2 \%)$ on yield and quality of guava cv. Allahabad Safeda. The design of experiment was Randomised Block Design (RBD) with factorial arrangement. The results of the study indicated that foliar spray of $50 \mathrm{ppm}$ 2,4-D was found to be the best for increasing yield( $47.39 \mathrm{Kg} / \mathrm{tree})$. Maximum fruit length at harvest $(8.90$ $\mathrm{cm})$, fruit weight(203.0 g) were recorded under foliar application of $100 \mathrm{ppm}$ NAA. Various quality parameters namely total sugars(10.46\%),reducing sugars(4.99\%), non-reducing sugars(5.47\%) and $\operatorname{TSS}\left(11.05^{\circ}\right.$ Brix $)$ were also found to be improved with the application of $50 \mathrm{ppm} 2,4-\mathrm{D}$.
\end{abstract}

Copy Right, IJAR, 2017,. All rights reserved.

\section{Introduction:-}

Guava (Psidium guajava L.) which is also known as the Apple of tropics or the poor man's fruit is the fifth most widely grown fruit crop in India (Deepthi et al 2015). It belongs to family myrtaceae and is indigenous to tropical America stretching from Mexico to Peru (Agnihotri et al 2013). It is successfully grown all over the world in countries like Peru, Egypt, USA (Florida and Hawaii states), South Africa, Brazil, Mexico, Venezuela, Australia and Thailand. In India, guava occupies an area of 2083 lac ha with an annual production of 22.7 lac MT (Anon 2015b). The guava producing states in India are Punjab, Gujarat, Bihar, Madhya Pradesh and Tamil Nadu but the districts of Allahabad has a reputation of growing the best guava in the country as well as in the world (Dhillon 2013). In Punjab, guava is cultivated on a large scale in the districts of Patiala, Amritsar, Ropar, Ludhiana and Jalandhar occupying an area of 82.25 ha with an annual production of 180775 MT (Anon 2015a).

It possesses a high nutritive value as it is a good source of carbohydrates, minerals, iron, calcium and phosphorous. It is rich in dietary vitamin $\mathrm{C}$ with moderate levels of folic acid. Having a generally low calorie profile of essential nutrients a single common guava fruit contains four times the amount of vitamin C (Udemezue et al 2014). The fruit is also a very good source of vitamin A and flavonoids like beta carotene, lycopene, lutein and cryptoxanthin. The compounds are known to have antioxidant properties essential for optimum health. The fruit is also a moderate source of B-complex vitamins such as niacin, vitamin-B6 (Pyridoxine) vitamin $\mathrm{K}$, as well as minerals like magnesium, copper and manganese (Garasiya et al 2013). It has an astringent property due to which its mature leaves, fruits, roots and bark are used in medicines to treat gastroenteritis, diarrhea and dysentery (Ojewale et al 2008). The fruit is a very rich source of soluble dietary fiber which makes it a good bulk laxative. The fiber content 
in fruit protects the colon mucous membrane by decreasing the exposure time to toxins as well as binding to cancer causing chemicals in the colon. There is an increasing demand of fruits for fresh as well as processing purpose in domestic and international markets (Bisen et al 2014). The importance of plant growth regulators in achieving higher yield and better quality of fruit crops has been well recognized in recent time. According to Katiyar et al (2008) 2,4-D as well as NAA have been found to accelerate the translocation of metabolites in parts of the plant towards developing fruits and improve their quality by increasing their size, TSS, total sugars and ascorbic acid. Reduction in acidity have also been recorded in guava cv L-49 by the application of 2,4-D and NAA (Garisya et al 2013). The application of urea in guava also improved the quality of fruits (Sahay and Kumar 2004). Keeping in view the above facts the present study was therefore, planned to enhance the quality and yield of guava cv. Allahabad Safeda

\section{Materials And Methods:-}

The present study was carried out in the well maintained orchard and analysis was done in the laboratory of Department of Horticulture, Khalsa college, Amritsar during 2016-2017. The experiment was conducted in randomized block design. The experiments comprised of 10 treatments consisting of foliar spray of NAA, 2-4 D and urea. The treatments were $\mathrm{T}_{1}$ NAA $(50 \mathrm{ppm}), \mathrm{T}_{2} \mathrm{NAA}(75 \mathrm{ppm}), \mathrm{T}_{3}$ NAA (100 ppm), $\mathrm{T}_{4} 2,4-\mathrm{D}$ (30 ppm), T 2,4-D (40 ppm), $\mathrm{T}_{6} 2,4-\mathrm{D}(50 \mathrm{ppm}), \mathrm{T}_{7}$ urea $(1 \%), \mathrm{T}_{8}$ urea $(1.5 \%), \mathrm{T}_{9}$ urea $(2 \%)$ and $\mathrm{T}_{10}$ control. Spray was done at $50 \%$ flowering stage. The data on chemical parameters was recorded. Chemical parameters of fruits was determined by using average sized 10 fruits collected randomly from each replication. The TSS was determined with the help of a hand refractrometer. Sugars in the fruits were determined by the method given by A.O.A.C. (1990). Ascorbic acid was estimated by indophenols dye method.

\section{Results And Discussion:-}

Maximum fruit length $(8.92 \mathrm{~cm})$ was recorded in the fruits harvested from plants treated with NAA 100 ppm followed by $(8.46 \mathrm{~cm})$ with $2,4-\mathrm{D} 50 \mathrm{ppm}$ and $(8.16 \mathrm{~cm})$ with $2,4-\mathrm{D} 40 \mathrm{ppm}$ respectively. The treatment of NAA $75 \mathrm{ppm}$ recorded the fruit length of $(7.61 \mathrm{~cm})$ followed by 2,4-D $30 \mathrm{ppm}$ with $(7.53 \mathrm{~cm})$ and NAA 50 ppm with $(7.23 \mathrm{~cm})$ length respectively. The data followed the ascending trend in fruit length with an increase in the concentration of NAA and 2, 4-D. The descending trend was noted in the fruit length with an increase in concentration of urea. From the perusal of data it was also clear that urea treatment produced more fruit length as compared to control. Urea 1 per cent produced fruit length of $(7.22 \mathrm{~cm})$ followed by urea 2 per cent $(6.82 \mathrm{~cm})$ and urea 1.5 per cent with fruit length $(6.71 \mathrm{~cm})$ which was more than $(6.20 \mathrm{~cm})$ under control.

The fruit breadth was affected significantly by the foliar spray of NAA, 2, 4-D and urea as compared to control. Maximum fruit breadth $(9.26 \mathrm{~cm})$ was recorded in the fruits harvested from plants treated with 2, 4-D 50 ppm followed by 2, 4-D $40 \mathrm{ppm}$ and NAA $100 \mathrm{ppm}$ with fruit breadth of $(9.10 \mathrm{~cm})$ and $(8.93 \mathrm{~cm})$ respectively. The treatments of 2,4-D $30 \mathrm{ppm}$ recorded the fruit breadth of $(8.73 \mathrm{~cm})$, which was followed by $(8.56 \mathrm{~cm})$ with NAA 75 ppm and $(7.70 \mathrm{~cm})$ with NAA $50 \mathrm{ppm}$ respectively. Urea 1.5 per cent produced fruit breadth of $(7.11 \mathrm{~cm})$ which was followed by $(6.96 \mathrm{~cm})$ and $(6.72 \mathrm{~cm})$ with urea 1 per cent and urea 2 per cent respectively.

The increase in fruit size (length and breadth) might be due to the optimum supply of plant nutrients and growth regulators in right amount during the entire crop growth period causing vigorous vegetative development of the plant, ultimately leading to production of more photosynthates (Awasthi and Lal 2009). The application of NAA might have a role in increasing the auxin level of fruits, which in turn, might have helped in the development of fruit components as there is a direct correlation between auxin content and fruit growth. Increased level of carbohydrates stimulated cell division and cell elongation resulting in larger fruits. The improved fruit size in terms of length and breadth by plant growth regulators has also been reported by Yadav et al (2001), Agnihotri et al (2013), Iqbal et al (2009), Kumar et al (2010) and Jain and Dashora (2010) in guava.

The foliar application of NAA, 2, 4-D and urea had beneficial effects on the weight of guava fruit and these chemicals helped in increasing fruit weight significantly over control.The maximum fruit weight $(203.00 \mathrm{~g})$ was recorded in the fruits harvested from plants treated with NAA $100 \mathrm{ppm}$ which was followed by $(183.00 \mathrm{~g})$ with urea 2 per cent and $(170.67 \mathrm{~g})$ with urea 1 per cent. It is also evident from the data that all the treatments produced significantly superior fruits than control. The treatment of 2,4-D $50 \mathrm{ppm}$ recorded the fruit weight of (162.33 g) which was followed by $(160.33 \mathrm{~g})$ with NAA $75 \mathrm{ppm}$ and $(154.33 \mathrm{~g})$ with urea 1.5 per cent respectively. The treatments were further followed by 2, 4-D 30, 50 and $40 \mathrm{ppm}$ with $(152.33 \mathrm{~g}),(149.00 \mathrm{~g})$ and $(146.66 \mathrm{~g})$ fruit 
weight respectively. All the treatments significantly increased the fruit weight as compared to control which generated $(142.66 \mathrm{~g})$ respectively. Increase in fruit weight might be attributed to the exogenous supply of NAA which might have helped in strengthening of middle lamella and consequently cell wall and might have increased the mobilization of food materials and minerals from other parts of the plant towards developing fruits that are extremely active metabolic sink which, in turn could have increased the fruit weight (Katiyar et al 2009). These results are also in agreement with the reporting of Anawal et al (2015) in the pomegranate and Pandey et al (2001) in guava. Lal et al (2013) also resulted the same in guava. Kher et al (2005) and Yadav et al (2001) reported that the application of NAA (20,40,60 and $80 \mathrm{ppm})$ sprayed 15 days before harvest increased the fruit weight in guava due to accumulation of sugars and high pulp percentage in sprayed guava fruits. These results also corroborates the findings of Rajput et al (2016) respectively.

The perusal of data regarding fruit yield of guava cv. Allahabad Safeda indicated that different NAA, 2, 4-D and urea concentrations exerted a significant influence on fruit yield. Significantly higher fruit yield $(49.41 \mathrm{~kg}) \mathrm{was}$ obtained from the plants treated with 2,4-D $50 \mathrm{ppm}$ which was followed by $(47.39 \mathrm{~kg})$ with 2,4-D 40ppm and $(46.57$ $\mathrm{kg}$ ) with 2,4-D $30 \mathrm{ppm}$ respectively. NAA $100 \mathrm{ppm}$ registered $(43.78 \mathrm{~kg})$ yield followed by $(41.09 \mathrm{~kg})$ with NAA 75 ppm and $(39.12 \mathrm{~kg})$ with NAA $50 \mathrm{ppm}$ respectively. These treatments were further followed by Urea 2 per cent, 1.5 per cent and 1 per cent with $(34.36 \mathrm{~kg}),(33.42 \mathrm{~kg})$ and $(32.08 \mathrm{~kg})$ and minimum $(19.06 \mathrm{~kg})$ under control. Increase in fruit weight might be attributed to the strengthening of middle lamella and consequently cell wall, which later may have increased the free passage of solutes to the fruits. This might have lead to more length and diameter of fruits and also larger weight of individual fruit. There was positive and significant correlation between the length, weight and diameter of fruit. The increase in yield per plant is obviously due to increase in volume and weight of fruit. These results are in accordance with the findings of Dubey et al (2002), Rajput et al (2016), Agnihotri et al (2013) in guava respectively

It is evident from the data that all the treatments significantly affected the TSS. Maximum TSS (11.05\%) was recorded in 2, 4-D $50 \mathrm{ppm}$ and it was followed by 2, 4-D $40 \mathrm{ppm}$ (10.76\%) and NAA $100 \mathrm{ppm}(10.05 \%)$ TSS respectively. All the treatments were statistically at par with each other. The treatment of 2, 4-D $30 \mathrm{ppm}$ recorded the TSS of $(9.84 \%)$ which was followed by NAA $75 \mathrm{ppm}(9.76 \%)$, and NAA $50 \mathrm{ppm}(9.69 \%)$. These treatments were further followed by urea 1 per cent $(9.51 \%)$, urea 1.5 per cent $(9.52 \%)$ and urea 2 per cent $(9.5 \%)$ respectively. TSS content of the fruits under control was the least amounting to (9.18\%). Rajput et al (2015) reported that the TSS was increased due to its action on converting complex substances into simple ones, which enhanced the metabolic activity in fruits. The increase might be due to an increase in the mobilization of carbohydrates from the source of sink (fruits) by auxins. This might be attributed to the fact that NAA might have increased amylase activity and thus there was quick metabolic transformation of starch into soluble sugars and early ripening in response to growth substances lead to an increase in TSS. The results of the present study are in agreement with the findings of Agnihotri et al (2013) in guava. Similar results were also obtained by Dubey et al (2002).

It is clearly indicated from the data that the effect of NAA, 2,4-D and urea registered significant effects on titratable acidity. Acidity of fruits was reduced by the application of all the chemicals, however maximum reduction was noted with the foliar spray of $100 \mathrm{ppm}$ NAA. The treatment of 2,4-D $50 \mathrm{ppm}$ recorded the acidity of 0.33 per cent and it showed decrease in acidity with the increased concentration. The fruits under control registered the maximum acidity of 0.39 per cent. The lower acidity might be due to an early ripening of fruits caused by the treatment, where acid might have been used during respiration or fastly converted into sugars and their derivatives by reactions involving reverse glycolytic pathways or might have been used in respiration or both (Agnihotri et al 2013) (Rajput et al 2016). Similar results were obtained by Dubey et al (2002) and Katiyar et al (2008) in guava. The findings of Brar et al (2012) and Garasiya et al (2013) are also in line with the present studies.

The maximum TSS:acid ratio (35.89) was calculated in plants treated with NAA $100 \mathrm{ppm}$ followed by TSS:acid ratio of (33.48) with 2,4-D $50 \mathrm{ppm}$. The minimum TSS:acid ratio (23.54) was found under control. These results are in accordance with the findings of Agnihotri et al (2013) in guava cv. Chittidar.

The data on effect of foliar application of NAA 2,4-D and urea on total sugars of fruits in guava cv. Allahabad Safeda depicted that significantly higher total sugars (10.46\%) were analysed from the fruits treated with 2,4-D 50 ppm followed by 2,4-D $40 \mathrm{ppm}$ with $(10.31 \%)$ and NAA $100 \mathrm{ppm}$ with $(10.04 \%)$ total sugars. Treatment of 2,4-D $30 \mathrm{ppm}$ registered $(9.84 \%)$ total sugars followed by NAA $75 \mathrm{ppm}$ with $(9.64 \%)$ and NAA $50 \mathrm{ppm}$ with $(9.43 \%)$ respectively. Control registered the lowest (8.64\%)total sugars. The increase in total sugars might be due to the fact 
that growth regulators being helpful in the process of photosynthesis led to the accumulation of oligosaccharides and polysaccharides in higher amount. Besides this, they also regulates the enzymatic activity and the enzymes quickly metabolized the starch into soluble sugars and early ripening in response to growth substances. Similar observations were recorded by Agnihotri et al (2013), Dutta and Banik (2007), Kher et al (2005) in guava.

Data regarding effect of foliar application of NAA, 2,4-D and urea on reducing sugars of fruits of guava cv. Allahabad Safeda are presented in Table 4.16 and Figure 4.15. From the perusal of data it is clear that NAA, 2,4-D and urea exerted significant influence on the reducing sugars depicting the highest percentage of (4.98\%) recorded in the fruits treated with 2,4-D $50 \mathrm{ppm}$ followed by 2,4-D $40 \mathrm{ppm}$ with $(4.91 \%)$ and NAA $100 \mathrm{ppm}$ with (4.87\%) reducing sugars respectively. These treatments are further followed by urea 1.5 per cent with $(4.13 \%)$, urea 2 per cent with $(4.05 \%)$ and urea 1 per cent with (3.97\%) reducing sugars respectively. Minimum reducing sugars of $(3.82 \%)$ were recorded in the fruits under control. This might be due to the quick metabolic transformation of starch into soluble sugars. These results are in collaboration with the findings of Agnihotri et al (2013).

The data on effect of foliar application of NAA, 2,4-D and urea on reducing sugars of fruits in guava cv. Allahabad Safeda presented in Table 4.17 and Figure 4.16 depicted that significantly higher non reducing sugars $(5.48 \%)$ were analysed from the fruits treated with 2,4-D 50 ppm followed by 2,4-D 40 ppm with (5.4\%) and 2, 4-D 30 ppm with $(5.19 \%)$ reducing sugars respectively. Treatment of NAA 100 ppm registered $(5.17 \%)$ non-reducing sugars followed by urea 1.5 per cent with $(5.05 \%)$ and NAA 75 ppm with $(5.03 \%)$ non-reducing sugars. These treatments were further followed by urea 1 per cent with (4.99\%), NAA 50 ppm with (4.92\%) and urea 2 per cent with (4.86\%) non reducing sugars respectively. Control registered the lowest non-reducing sugars percentage that is (4.82\%).The better sugar content might be obtained by the synergetic effect of plant growth regulators. The research work of Agnihotri et al (2013) is also in line with the present studies.

The data pertaining to the ascorbic acid content clearly indicated that the different concentrations of NAA, 2, 4-D and urea exerted a significant influence on vitamin $\mathrm{C}$ with the highest $(260.33 \mathrm{mg} / 100 \mathrm{~g})$ content obtained from the plants treated with urea 2 per cent followed by urea 1.5 per cent and 2,4-D 40 ppm with $(249.86 \mathrm{mg} / 100 \mathrm{~g})$ and (248.93mg/100g). 2, 4-D $50 \mathrm{ppm}$ registered vitamin C content $(248.86 \mathrm{mg} / 100 \mathrm{~g})$ followed by $(247.03 \mathrm{mg} / 100 \mathrm{~g}) \mathrm{with}$ 2, 4-D $30 \mathrm{ppm}$ and $(241.96 \mathrm{mg} / 100 \mathrm{~g})$ with urea 1 per cent respectively. Minimum range of ascorbic acid $(228.36 \mathrm{mg} / 100 \mathrm{~g})$ was obtained under controlled conditions. These results are in agreement with the findings of Agnihotri et al (2013). This might be attributed to the fact that quick metabolic transformation of starch into soluble sugars and early ripening in response to growth regulators resulted in the good ascorbic acid content. The increase in ascorbic acid content might have resulted owing to biosynthesis of ascorbic acid from sugar or inhibition of oxidative enzymes or both due to favourable metabolic activity involving certain enzymes and metabolic ions under the influence of plant growth regulators and micro-nutrients (Rajput et al 2016). An increase in ascorbic acid content might be due to perpetual synthesis of glucose-6-phosphate throughout the growth and development of fruits which is thought to be the precursor of vitamin C. The research findings of Bariana and Dhaliwal (2002) also advocated the same in guava fruits cv. Sardar. The earlier findings of Singh et al (2002) and Sharma et al (2011) in guava are also in consonance with the present results.

\section{Conclusion:-}

It is concluded from the present study that 2,4-D $50 \mathrm{ppm}$ proved to be the most effective treatment in enhancing the fruit yield and improving the fruit quality as compared to other treatments of NAA and urea.

Table1:- Effect of growth regulators on fruit characters and yield of guava cv. Allahabad Safeda.

\begin{tabular}{|l|l|l|l|c|}
\hline Treatments & \multicolumn{1}{|c|}{ Fruit size $(\mathbf{l} \times \mathbf{b})$} & Fruit weight $(\mathbf{g})$ & Fruit yield(g) \\
\hline & Length $\mathbf{( c m )}$ & Breadth $(\mathbf{c m})$ & & \\
\hline T1- NAA 50ppm & 7.23 & 7.70 & 149.01 & 39.12 \\
\hline T2-NAA 75 ppm & 7.61 & 8.56 & 160.33 & 41.09 \\
\hline T3-NAA 100 ppm & 8.92 & 8.93 & 203.00 & 43.78 \\
\hline T4-2,4-D 30 ppm & 7.53 & 8.73 & 152.33 & 46.57 \\
\hline T5-2,4-D 40 ppm & 8.16 & 9.10 & 146.67 & 47.39 \\
\hline T6-2,4-D 50 ppm & 8.46 & 9.26 & 162.33 & $\mathbf{4 9 . 4 1}$ \\
\hline T7-Urea 1\% & 7.22 & 6.96 & 170.67 & 32.08 \\
\hline T8-Urea 1.5\% & 6.71 & 7.11 & 154.33 & 33.42 \\
\hline
\end{tabular}




\begin{tabular}{|l|l|l|l|l|}
\hline T9-Urea 2\% & 6.82 & 6.72 & 183.00 & \multicolumn{1}{|c|}{34.36} \\
\hline T10-Control & 6.20 & 6.11 & 142.67 & 19.06 \\
\hline Mean & 7.48 & 7.91 & 162.43 & 38.62 \\
\hline CD at 5\% level & 0.89 & 0.37 & 7.22 & 5.66 \\
\hline
\end{tabular}

Table 2:-Effect of growth regulators on fruit quality of guava cv. Allahabad Safeda.

\begin{tabular}{|l|l|l|c|c|c|c|c|}
\hline Treatments & TSS\% & $\begin{array}{l}\text { Acidity } \\
(\boldsymbol{\%})\end{array}$ & Tss: acid & $\begin{array}{l}\text { Total } \\
\text { sugars } \\
(\boldsymbol{\%})\end{array}$ & $\begin{array}{l}\text { Reducing } \\
\text { sugars } \\
(\boldsymbol{\%})\end{array}$ & $\begin{array}{l}\text { Non } \\
\text { reducing } \\
\text { sugars(\%) }\end{array}$ & $\begin{array}{l}\text { Ascorbic } \\
\text { acid } \\
(\mathbf{m g} / \mathbf{1 0 0 g})\end{array}$ \\
\hline T1- NAA 50 ppm & 9.69 & 0.31 & 31.25 & 9.43 & 4.51 & 4.92 & 240.36 \\
\hline T2-NAA 75 ppm & 9.76 & 0.30 & 32.53 & 9.64 & 4.59 & 5.05 & 235.63 \\
\hline T3-NAA 100 ppm & 10.05 & 0.28 & 35.89 & 10.04 & 4.87 & 5.17 & 238.46 \\
\hline T4-2,4-D 30 ppm & 9.84 & 0.36 & 27.33 & 9.84 & 4.65 & 5.19 & 247.03 \\
\hline T5-2,4-D 40 ppm & 10.76 & 0.34 & 31.64 & 10.31 & 4.91 & 5.40 & 248.93 \\
\hline T6-2,4-D 50 ppm & 11.05 & 0.33 & 33.48 & 10.46 & 4.98 & 5.48 & 248.86 \\
\hline T7-Urea 1\% & 9.57 & 0.38 & 25.19 & 8.96 & 3.97 & 4.99 & 241.96 \\
\hline T8-Urea 1.5\% & 9.52 & 0.37 & 25.75 & 9.17 & 4.13 & 5.04 & 249.86 \\
\hline T9-Urea 2\% & 9.51 & 0.35 & 27.21 & 8.91 & 4.05 & 4.86 & 260.33 \\
\hline T10-Control & 9.18 & 0.39 & 23.54 & 8.64 & 3.82 & 4.82 & 228.36 \\
\hline Mean & 9.89 & 0.34 & 29.38 & 9.54 & 4.44 & 5.09 & 243.97 \\
\hline CD at 5\% level & 0.20 & 0.02 & 0.08 & 0.08 & 0.04 & 0.08 & 9.89 \\
\hline
\end{tabular}

\section{References:-}

1. AOAC Washington (1990) Official methods of analysis. $14^{\text {th }}$ edn. Association of official Agricultural chemists. Washington, D.C., USA.

2. Agnihotri A, Tiwari R and Singh OP (2013). Effect of crop regulators on growth, yield and quality of guava. Annuals of Plant and Soil Research 15-54:57.

3. Anon (2015,a). Package and practices of fruits PAU, Ludhiana.

4. Anon $(2015, b)$. Area and production under fruits in India NHB Bulletin.

5. AOAC Washington (1990). Official methods of analysis. $14^{\text {th }}$ edn. Association of official Agricultural chemists. Washington, D.C., USA.

6. Awasthi P and Lal S (2009) Effect of calcium, boron, and zinc and foliar sprays on yield and quality of guava (Psidium guajava L.). Pantnagar J Res 7: 223-225.

7. Bariana D and Dhaliwal GS (2002) Effect of chemicals on fruit quality and yield of winter season crop of guava cv. Sardar. J Res Punjab agric Univ 39: 508-12.

8. Bisen S, Thakur, RS and Tembhare D (2014). Effect of calcium nitrate and gibberllic acid application on growth, fruit quality and post harvest behaviour of guava fruit. 6: 55-62.

9. Brar JS, Dhaliwal HS, Bal JS, Dhillon WS and Singh SP (2012) Effect of spacing on canopy microclimate, vegetative growth and yield attributes in guava (Psidium guajava L.). J of Horti Sci. 7: 41-75.

10. Deepthi PV, Shekhar C and Srihari D (2015). Effect of maturity stage and NAA, GA 3 and BA on the organoleptic quality of guava fruits cv. Lucknow-49 during cold storage. International Journal of Current Research 7: 19395-19405.

11. Dhillon WS (2013). Fruit production in India. Narendra Publication House, New Delhi- 11006 (India).

12. Dubey AK, Singh DB and Dubey N (2002). Crop regulation in guava (Psidium guajava L.) cv. Allahabad Safeda. Prog. Hort., 34:200-203.

13. Dutta P and Banik AK (2007) Effect of foliar feeding of nutrients and plant growth regulators on physicochemical quality of sardar gava growth in red and lateritic tract of West Bengal. Acta Hortic. 735-57.

14. Garasiya VR, Patel NM, Bhaduria HS and Wankhade VR (2013). Effect of plant growth regulators on quality of winter season guava (Psidium guajava L.) cv. L-49 (Sardar). Asian Journal of Horticulture 8 :347-349.

15. Iqbal M, Khan MQ, Jalal-ud-Din, Khalid Rehman and Munir M (2009) Effect of foliar application of NAA on fruit drop, yield and physical-chemical characteristics of guava (Psidium guajava L.) Red Flesh cultivar. J Agric Res. 47: 259-269.

16. Jain MC and Dashora LK (2010) Effect of different plant bio-regulators in relation to fruit quality and yield of guava cv. Sardar. Prog Hortic. 42: 50-53. 
17. Katiyar PN, Singh JP, Singh PC and Gangawar APS. (2008). Effect of pre-harvest application of plant growth regulators on post harvest quality of originally grown guava (Psidium guajava L.) fruits. Asian Journal of Horticulture 3: 330-332.

18. Kher R, Bhat S and Wali VK (2005) Effect of foliar application of GA3, NAA and CCC on physico-chemical characteristics of guava cv. Sardar. Haryana J Hort Sci. 34: 31-32.

19. Kumar S, Singh AK and Yadav AL (2010) Effect of foliar application of $\mathrm{GA}_{3}, \mathrm{NAA}, \mathrm{KNO}_{3}$ and Borax on fruit quality of rainy season guava cv. Lucknow-49. J Plant Archi. 10: 317-319.

20. Lal N, Das RP and Verma LM (2013) Effect of plant growth regulators on flowering and fruit growth of guava (Psidium guajava L.) cv. Allahabad Safeda. The Asi J of Hort. 8: 54-56.

21. Ojewole JA, Awe EO and Chiwororo W (2008). Anti diarrhoeal activity of Psidium guajava L. leaf aqueous extracts in rodents. Journal of Smooth Muscle Research 44: 195-207.

22. Pandey DK, Goswamy CL and Kumar R (2001) Effect of plant growth regulators on photosynthesis under water logging. Indian J Plant Physio. 6: 90-94.

23. Rajput RP, Senjaliya HJ, Vala GS and Mangroliya GS (2016) Effect of various plant growth regulators on yield and quality of guava (Psidium guajava L.) cv. Lucknow-49. Inter J Agric Sci. 11: 179-182.

24. Sahay S and Kumar N (2004). Crop regulation and quality control in guava(Psidium guajava L.). Prog Hort. 36: $152-154$

25. Singh G, Singh AK, Rajan S and Bhriguvanshi SR (2002) Strategy for crop regulation in guava (Psidium guajava L.) through foliar urea sprays and its effect on different $\mathrm{N}$-from in leaves. J Appl Hort. 4: 93-98.

26. Sharma J, Sharma SK, Panwar RD and Gupta RB (2011) Fruit retention yield and leaf nutrient content of ber as influence by foliar application of nutrients and growth regulators. Envi. and Ecology. 28: 627-631.

27. Udemezue OO, Ukoha O, Ezejindu DN, Okafor, JI and Obilor AD (2014). The effect of leaf extract of guava on the liver enzymes of adult wistar ots. Int J Sci and Res Publication 6: 2250-3153.

28. Yadav S, Bhatia SK, Godara RK and Rana GS (2001) Effect of growth regulators on the yield quality of winter season guava cv. L-49. Har J Hort Sci. 30 :1-2. 